\title{
Morbillivirus infections of aquatic mammals: newly identified members of the genus
}

\author{
Albert D.M.E. Osterhaus ${ }^{\text {a,b,*, Rik L. de Swart }}{ }^{\text {, }}$, Helma W. Vos ${ }^{\text {, }}$, \\ Peter S. Ross ${ }^{b}$, Marcel J.H. Kenter ${ }^{a}$, Tom Barrett ${ }^{c}$ \\ ${ }^{a}$ Department of Virology, Erasmus University, P.O. Box 1738, 3000 DR Rotterdam, Netherlands \\ ${ }^{\mathrm{b}}$ Seal Rehabilitation and Research Centre, Hoofdstraat $94 a, 9968$ AG Pieterburen, Netherlands \\ ' Institute for Animal Health, Pirbright Laboratory, Ash Road, Pirbright, Woking GU24 ONF, UK
}

Accepted 4 January 1995

\begin{abstract}
Several disease outbreaks, which have caused the deaths of many thousands of seals and dolphins during the last decade, have now been attributed to infections with newly identified Morbilliviruses. Outbreaks in the late eighties amongst harbour seals (Phoca vitulina) and grey seals (Halichoerus grypus) in northwestern Europe and amongst baikal seals (Phoca sibirica) in Siberia were caused by the newly discovered phocine distemper virus and by a strain of canine distemper virus, respectively. Although closely related these two viruses were not identical. They were more distantly related to the viruses which caused mass mortality amongst striped dolphins (Stenella coeruleoalba) in the Mediterranean sea in the early nineties. This dolphin morbillivirus was shown to be closely related to a virus that was found in harbour porpoises (Phocoena phocoena) which had stranded at the coasts of northwestern Europe in the late eighties: porpoise morbillivirus. The present knowledge of the genetic and antigenic relationships of these apparently new members of the genus Morbillivirus with the established members of the genus is presented. In addition, the origin and epizootiological aspects of these newly discovered viruses are discussed. Finally experimental evidence that environmental pollution may have contributed to the severity and extent of these infections in recent years is presented.
\end{abstract}

Keywords: Morbillivirus; Mammal, aquatic; Pollution

\section{Introduction}

After it was demonstrated in 1988 that a morbillivirus which had not been previously identified, phocine distemper virus (PDV), was the primary cause of the mass mortality

* Corresponding author. Tel: +3110408 8066, Fax: +31 104365145 . 
amongst harbour seals (Phoca vitulina) and grey seals (Halichoerus grypus) in northwestern Europe, several other outbreaks of mass mortality amongst aquatic mammals were attributed to infection with established and newly discovered members of the genus Morbillivirus of the family Paramyxoviridae (for review see Visser et al., 1993a). A serious disease outbreak amongst baikal seals ( Phoca sibirica) caused by canine distemper virus (CDV), had actually started before the northwest European distemper outbreak, in 1987. Strandings of relatively small numbers of harbour porpoises (Phocoena phocoena) during the PDV outbreak at the coasts of northwestern Europe, were shown to be caused by a virus distinct from PDV that is now named porpoise morbillivirus (PMV).

A closely related virus caused mass mortality amongst striped dolphins (Stenella coeruleoalba) in the Mediterranean sea at the beginning of the nineties. This dolphin morbillivirus (DMV) and PMV were both quite distinct from the morbilliviruses of aquatic and terrestrial carnivores, PDV and CDV, and were shown to be genetically and antigenically more closely related to the morbilliviruses of ruminants: rinderpest virus (RPV) and peste des petits ruminants virus (PPRV).

Although some questions about the origin and epizootiology of these viruses still need to be answered, it becomes more and more clear that morbillivirus infections have a major regulatory effect on population sizes of several species of aquatic mammals as is seen also in terrestrial mammals. Speculations about the sudden appearance of these morbillivirus infections in a relatively short period of time, and a possible triggering effect of environmental pollution causing an impaired immune response, have now been addressed experimentally.

\section{Morbillivirus phylogeny: Where to place the newly recognized members?}

After the identification of the causative agent of the outbreak amongst harbour and grey seals in northwestern Europe as " a morbillivirus closely related if not identical to CDV" many studies have been carried out to characterize further the morbillivirus involved in this outbreak. The first identification was based on a serological study in which paired serum samples from affected animals were tested in a CDV neutralization test (Osterhaus and Vedder, 1988). On the basis of these serological data, in combination with the clinical signs and pathological lesions found in infected seals, which appeared to be quite similar to those observed in dogs with canine distemper, it was concluded that a morbillivirus was the primary cause of the outbreak (Osterhaus et al., 1988). The virus was subsequently isolated, SPF dogs were experimentally infected and it was shown that these animals developed mild clinical signs of canine distemper and CDV neutralizing serum antibodies (Visser et al., 1990). Final proof for the aetiologic role of the morbillivirus in the outbreak, came from a vaccination experiment in which captive seals vaccinated with inactivated CDV vaccines proved to be protected from a fatal challenge with organ material from seals that had died during the outbreak (Osterhaus et al., 1989a; Visser et al., 1989).

During the outbreak of a similar disease in Baikal seals, that had started in 1987, the causative role of a morbillivirus was also established. Disease symptoms, histopathological lesions and CDV neutralizing serum antibodies were demonstrated (Grachev et al., 1989; Osterhaus et al., 1989b). SPF dogs were infected with organ material from these seals. 
They developed mild clinical signs and CDV neutralising serum antibodies (Visser et al., 1990). The virus was isolated and was tentatively named phocine distemper virus 2 (PDV2) to distinguish it from PDV which we refer to as PDV-1 in this paper. PDV-1, PDV-2 and CDV were subsequently compared with respect to their biological, morphological, physical, protein chemical and antigenic properties. From these studies it became clear that PDV-1 should probably be considered a new member of the genus, and that PDV-2 was closely related to, or perhaps even a strain of CDV. This was based on relative mobilities $\left(\mathrm{M}_{\mathrm{r}}\right)$ of viral proteins, cross-reactivities of sera from naturally and experimentally infected seals and dogs in virus neutralization (VN) assays, and on reactivity patterns of panels of monoclonal antibodies raised against CDV and PDV-1 (Visser et al., 1990). Nucleotide sequence analysis of the NP, P, M, H and F genes carried out by different groups, confirmed that PDV-1 was distinct from CDV, with amino acid homologies between the respective $F_{0}, H, M, N P$ and $P$ proteins of 65 to $85 \%$ (Haas et al., 1991; Kövamees et al., 1991; Blixenkrone-Møller et al., 1992; Sharma et al., 1992; Visser et al., 1993c). Comparison of the PDV-2 F gene with other morbillivirus F genes for which sequence data are available, revealed a $91 \%$ similarity to the complete CDV F gene, and a $97 \%$ similarity when only the coding regions of the $\mathrm{F}$ gene were compared. This level of sequence variation is similar to that observed when different isolates of, for example, RPV are compared (Chamberlain et al., 1994; Visser et al., 1993c). More sequence data especially from different CDV strains isolated from terrestrial mammals in Siberia should be determined before the origin of PDV2 can be identified conclusively.

A phylogenetic tree based on the $F_{0}$ encoding region of PDV-1, PDV-2, CDV, RPV and measles virus (MV) genes (Fig. 1), shows the phylogenetic relationship of PDV-1 and PDV-2 with the other members of this genus.

When, during the 1988 PDV-1 outbreak amongst seals of northwest Europe, morbillivirus antigen was detected in harbour porpoises that had stranded along the Irish coast (Kennedy et al., 1988), and we subsequently isolated a morbillivirus from a harbour porpoise that had stranded along the Dutch coast (Visser et al., 1993b), it was initially assumed that the virus concerned would be identical to PDV-1. At that time no further attention was paid to the characterization of this virus. In 1990 we found evidence for a morbillivirus infection in a white beaked dolphin (Lagenorhyncus albirostris) that had stranded on the Dutch coast,

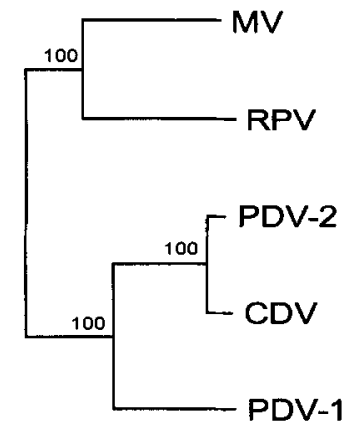

0.109

Fig. 1. Phylogenetic tree based on sequence analysis of $F_{0}$ encoding regions of morbillivirus fusion protein ( $F$ ) genes of different morbilliviruses. Numbers on the tree refer to bootstrap percentages, branch length is proportional to the genetic distance and is indicated by a bar. (Taken from Visser et al., 1993c). 
by detecting morbillivirus antigen in the lungs of this animal (unpublished observation). In that same year an outbreak of an apparently infectious disease started in the western part of the Mediterranean sea amongst striped dolphins (Domingo et al., 1990; Van Bressem et al., 1991). The epizootic moved eastward and reached the Turkish coast in 1992. Several morbillivirus isolates from dolphins stranded during this outbreak and from porpoises mentioned above were first compared antigenically with PDV-1 and CDV, using panels of CDV, PDV-1 and MV specific monoclonal antibodies. It was shown that DMV and PMV were antigenically closely related viruses, quite distinct from CDV and PDV-1. Serum antibodies in these and in other stranded cetacean species, like white beaked dolphins and common dolphins (Delphinus delphis), showed the highest and almost identical VN antibody titres towards PMV and DMV (Visser et al., 1993b; Van Bressem et al., 1993).

Comparison of a sequence of the $P$ gene encoding the RNA editing site from all presently known members of the genus, confirmed that DMV and PMV are closely related members of the genus, quite different from all other members, and form a distinct lineage more closely related to the ruminant than to the carnivore morbilliviruses (Barrett et al., 1992, 1993). A phylogenetic tree based on this $P$ gene region of the presently known morbilliviruses (Fig. 2) shows the phylogenetic relationship of the newly discovered viruses with the established members of the genus.

It is interesting to note that large and small ruminants (cattle, sheep and goats) were susceptible to infection with DMV and PMV, which both caused a mild leucopenia in these specics. Also dogs could be infected experimentally with these viruses. Pre-exposure to DMV or PMV protected dogs from developing CDV viraemia and clinical signs, upon challenge infection with virulent CDV (Visser et al., 1993b). It was speculated to be unlikely that DMV or PMV would infect ruminants or dogs under natural circumstances, since morbillivirus infections in general seem to be restricted to one order of mammalian species (Black, 1991). However, in recent years CDV has been found in many other carnivorous species, including seals (Grachev et al., 1989; Osterhaus et al., 1989b), javelinas (Tayassu

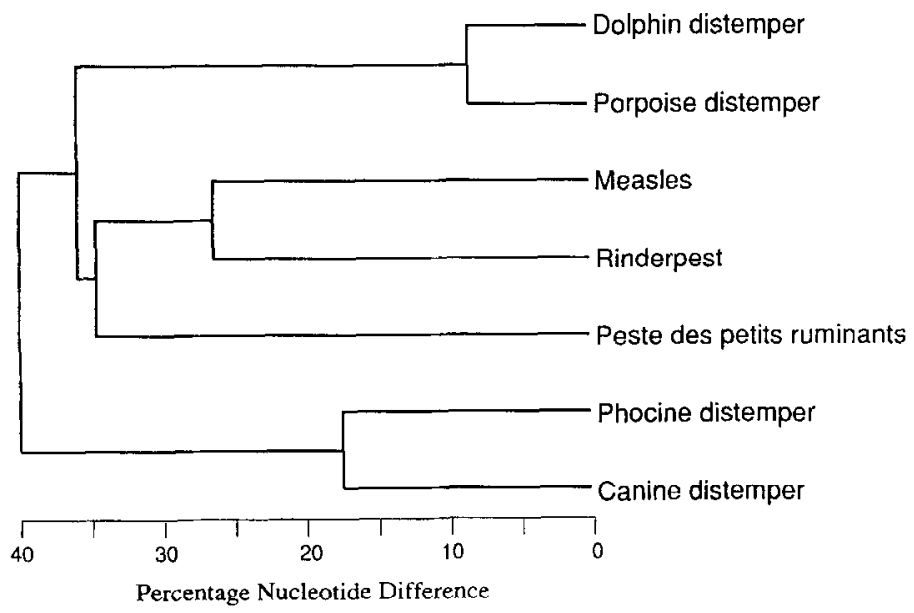

Fig. 2. Phylogenetic tree based on sequence analysis of highly conserved regions of the phosphoprotein (P) genes of different morbilliviruses. The percentage of nucleotide difference between the viruses is indicated. (Taken from Barrett et al., 1993). 
Table 1

Species susceptible to infection with different morbilliviruses (Based on Visser et al., 1993a, with additional data from Appel et al., 1994).

\begin{tabular}{|c|c|c|c|c|c|}
\hline & \multicolumn{3}{|l|}{ Natural infection } & \multicolumn{2}{|c|}{ Experimental infection } \\
\hline & Domestic species & Wild species & & Domestic species & Wild species \\
\hline MV & $\begin{array}{l}\text { humans } \\
\text { primates }\end{array}$ & (primates) & & $\begin{array}{l}\text { macaques } \\
\text { marmoset } \\
\text { mouse } \\
\text { hamster } \\
\text { rat }\end{array}$ & \\
\hline RPV & $\begin{array}{l}\text { cattle } \\
\text { buffalo } \\
\text { pig } \\
\text { goat/sheep }\end{array}$ & $\begin{array}{l}\text { (African) } \\
\text { buffalo } \\
\text { eland } \\
\text { giraffe } \\
\text { kudu } \\
\text { warthog } \\
\text { wildebeest }\end{array}$ & $\begin{array}{l}\text { (Asian) } \\
\text { banteng } \\
\text { blackbuck } \\
\text { gaur } \\
\text { nilgai } \\
\text { sambhar }\end{array}$ & $\begin{array}{l}\text { cattle } \\
\text { rabbit }\end{array}$ & \\
\hline PPRV & goat/sheep & $\begin{array}{l}\text { gazelle } \\
\text { ibex } \\
\text { gemsbok }\end{array}$ & & $\begin{array}{l}\text { goats } \\
\text { cattle } \\
\text { pig }\end{array}$ & deer \\
\hline PMV & & porpoise & & $\begin{array}{l}\text { cattle } \\
\text { sheep/goat } \\
\text { dog }\end{array}$ & \\
\hline DMV & & dolphins & & $\begin{array}{l}\text { cattle } \\
\text { sheep/goat } \\
\text { dog }\end{array}$ & \\
\hline CDV & $\operatorname{dog}$ & $\begin{array}{l}\text { Canidae } \\
\text { Mustellidae } \\
\text { Procyonidae } \\
\text { Felidae }\end{array}$ & $\begin{array}{l}\text { (e.g. fox) } \\
\text { (e.g. ferret) } \\
\text { (e.g. raccoon) } \\
\text { (e.g. lion) }\end{array}$ & $\begin{array}{l}\text { dog } \\
\text { mouse } \\
\text { rat/hamster } \\
\text { mink } \\
\text { pig } \\
\text { cat }\end{array}$ & ferret \\
\hline PDV & & seal & & $\begin{array}{l}\text { dog } \\
\text { mink }\end{array}$ & seal \\
\hline
\end{tabular}

tajacu) (Appel et al., 1991) and lions, tigers and leopards (Panthera spp.) (Appel et al., 1994). The susceptibility of different terrestrial and aquatic mammal species to natural and experimental infection with the presently identified morbilliviruses is shown in Table 1.

\section{Origin and epizootiological aspects of the newly recognized morbilliviruses}

The origin of PDV-1 has been the subject of many speculations during and after the outbreak in 1988. Original speculations about the possible role of simultaneously occurring CDV infections in sledge dogs in Greenland (Dietz et al., 1989) could readily be dismissed after the characterization of the virus as a new member of the genus. However, interspecies transfer of virus still seems the most likely explanation. That this may occur with PDV-1 was first demonstrated by showing experimental infection of dogs (Osterhaus et al., 1988; 
Visser et al., 1990; Visser et al., 1993b) and the infection of minks after contact with infected seals (Blixenkrone-Møller et al., 1990). We also showed the presence of PDV-1 or a closely related morbillivirus in healthy seals on the east coast of Canada before the outbreak took place in northwestern Europe (Ross et al., 1992). Extensive serological surveys that have been and are being conducted at present by us and others, have shown that morbilliviruses similar to PDV-1 are quite prevalent among pinniped species in the Arctic and other regions of North and South America (Duignan et al., 1994). The most likely link between the seals of the new and the old world is the harp seal (Phoca groenlandica), which bridges the North American and European seal populations and has been shown to be infected with a PDV-like virus (Dietz et al., 1989; Stuen et al., 1994). Interestingly, a mass migration of this species to the North European fishing waters was observed in the period directly preceding the 1988 outbreak.

How long PDV-1 will persist in the European seal population is hard to predict. Important factors are time of persistence in individual seals, degree of social contacts, migration patterns, general health status and major histocompatibility complex diversity. We have recently documented that PDV-1 was still circulating in the harbour seal population in the Dutch Waddensea until 1992 (Visser et al., 1993d), and continued to do so in 1993 (unpublished observation).

The origin of PDV-2 is probably CDV from a local terrestrial carnivore (Grachev et al., 1989). Speculations about the possibility that the origin was a vaccine strain of CDV used locally for vaccination of dogs can be dismissed. The nucleotide sequence of the $\mathrm{H}$ gene more closely resembles that of current wild type European viruses than that of the vaccines (Mamaev et al., 1995). A link between sledge dogs suffering from CDV infections and an outbreak of mass mortality among crabeater seals (Lobodon carcinophagus) in the Antarctic region in 1955 (Bengtson et al., 1991) suggests that these kinds of interspecies transmission do occur.

Analysis of serum antibody profiles of different species of cetaceans that have stranded at the coasts of Europe, showed that the majority of stranded animals had morbillivirus neutralizing antibodies, which reacted most strongly with PMV and DMV. However, a minor reactivity with CDV could be demonstrated (Visser et al., 1993b). This shows that morbilliviruses of the PMV/DMV lineage, which should probably be considered a separate serotype, are enzootic among several cetacean species. It is also tempting to speculate about a possible role of these infections in mass strandings of cetaceans (see Duignan et al., 1995).

Based on the phylogenetic relationship it may be concluded that it is unlikely that the PMV/DMV lineage has its origin in terrestrial animals. The phylogenetic relationship between the different morbilliviruses of aquatic mammals largely parallels the phylogenetic relationship of the animal species they infect (Visser et al., 1993a). Common viral ancestors may have acquired access to phylogenetically related animal species on the basis of biological similarities: CDV and PDV-1 probably share a common ancestor, which may also be the case for the PMV/DMV and the RPV/PPRV lineages.

The process of interspecies transmissions of morbilliviruses under natural conditions is usually restricted to transmission between members of the same mammalian order. In this light, the recent transmission of CDV infections from wild carnivores to leopards and lions, 
resulting in serious mortality in these cats, is an interesting phenomenon (Appel et al., 1994; Morell, 1994).

In conclusion, it may be stated that the PDV-1 and PMV/DMV infections of pinniped and cetacean species have probably been enzootic in these animals for a long time. Only when these viruses have not been present in a certain population for a long period, and consequently no specific immunity is present in this population, may introduction by, for example, interspecies transmission, lead to severe outbreaks accompanied with mass mortalities. This is similar to the situation in terrestrial mammals, including humans (Norrby and Oxman, 1990).

Although interspecies transmissions may in principle be considered natural events, they may be facilitated by anthropogenic factors. Outbreaks after contacts with domestic or wild animals changing their migration patterns as occurred with sledge dogs (Grachev et al., 1989) and harp seals (Dietz et al., 1989) respectively, are probably good examples.

\section{Did environmental pollution play a role in the recent morbillivirus outbreaks?}

Marine mammals inhabiting polluted coastal areas accumulate high levels of environmental contaminants. Several abnormalities in the physiology of these animals have been attributed to exposure to these pollutants through the food chain (Helle et al., 1976; Bergman et al., 1992; Subramanian et al., 1987; Reijnders, 1986). It has been widely speculated that the recent high incidence of morbillivirus epizootics in aquatic mammals inhabiting polluted waters in industrialized areas, was related to an impairment of immune function in these animals (Osterhaus and Vedder, 1989; Olsson et al., 1992; Hall et al., 1992).

We have addressed this issue in a controlled experiment in captive seals, which were fed herring from the highly polluted Baltic sea or from the relatively uncontaminated Atlantic Ocean. Changes were shown in several immune functions of the seals fed polluted fish. These included impairment of in vitro natural killer and T cell responses (De Swart et al., 1993), and in vivo delayed type hypersensitivity and antigen-specific B cell responses (Ross et al., 1995). This was the first demonstration of impaired immunological functions in mammals associated with chronic exposure to environmental contaminants accumulated through the marine food chain.

Although the impaired immune functions measured do play an important role in the defence against morbillivirus infections, it remains difficult to determine whether pollution has indeed contributed significantly to the severity and the extent of the recent epizootics amongst marine mammals. We speculate that the observed immune suppression, in combination with other anthropogenic factors, has created conditions which facilitated the emergence of morbillivirus epizootics in aquatic mammals.

\section{References}

Appel, M.J.G., Reggiardo, C., Summers, B.A., Pearce-Kelling, S., Maré, C.J., Noon, T.H., Reed, R.E., Shively, J.N. and Örvell, C., 1991. Canine distemper virus infection and encephalitis in javelinas (collared peccaries). Arch. Virol., 119: 147-152. 
Appel, M.J.G., Yates, R.A., Foley, G.L., Bernstein, J.J., Santinelli, S., Spelman, L.H., Miller, L.D., Arp, L.H., Anderson, M., Barr, M., Pearce-Kelling, S. and Summers, B.A., 1994. Canine distemper epizootic in lions, tigers, and leopards in North America. J. Vet. Diagn. Invest. 6: 277-288.

Barrett. T., Crowther, J., Osterhaus, A.D.M.E., Subbarao, S.M., Groen, J., Haas, L., Mamaev, L.V., Titenko, A.M. Visser, I.K.G. and Bostock, C.J., 1992. Molecular and serological studies on the recent seal virus epizootics in Europe and Siberia. Sci. Total. Envir., 115: 117-132.

Barrett, T., Visser, I.K.G., Mamaev, L., Goatley, L., Van Bressem, M.F. and Osterhaus, A.D.M.E., 1993. Dolphin and Porpoise morbilliviruses are genetically distinct from Phocine Distemper Virus. Virology, 193: 10101012 .

Bengtson, J.L., Boveng, P., Franzen, U., Have, P., Heide-Jørgensen, M.-P. and Härkönen, T.J., 1991. Antibodies to canine distemper virus in antarctic seals. Marine Mammal Sci., 7: 85-87.

Bergman, A., Olsson, M. and Reiland, S., 1992. Skull-bone lesions in the baltic grey seal (Halichoerus grypus). Ambio, 21: 517-519.

Black, F.L., 1991. Epidemiology of paramyxoviruses. In: Kingsbury, D. (editor), The paramyxoviruses. New York, Plenum Press, pp. 509-536.

Blixenkrone-Møller, M., Svansson, V., Orvell, C. and Have, P., 1990. Phocid distemper virus - a threat to terrestrial mammals? Vet. Rec.. 127: 263-264.

Blixenkrone-Møller, M., Sharma, B., Varsanyi, T.M., Hu, A., Norrby, E. and Kövamees, J., 1992. Sequence analysis of the genes encoding the nucleocapsid proiein (NP) and phosphoprotein (P) of phocid distemper virus, and editing of the P gene transcript. J. Gen. Virol., 73: 885-893.

Chamberlain, R.W., Wamwayi, H.M., Hockley, E., Shaila, M.S., Goatley, L., Knowles, N.J. and Barrett, T., 1994. Evidence for different lineages of rinderpest virus reflecting their geographic isolation. J. Gen. Virol., 74: 2775-2780.

De Swart, R.L., Ross, P.S., Vedder, E.J., Timmerman, H.H., Heisterkamp, S.H., Van Loveren, H., Vos, J.G., Reijnders. P.J.H. and Osterhaus, A.D.M.E., 1993. Impairment of immunological functions in harbour seals ( Phoca vitulina) feeding on fish from polluted coastal waters. Ambio, 23: 155-159.

Dietz, R., Ansen, C.T. and Have, P., 1989. Clue to seal epizootic? Nature, 338: 627.

Domingo, M., Ferrer, L., Pumarola, M., Marco, A., Plana, J., Kennedy, S., McAlisky, M. and Rima, B.K., 1990. Morbillivirus in dolphins. Nature, 348: 21.

Duignan, P.J., Saliki, J.T., St. Aubin, D.J., House, J.A. and Geraci, J.R., 1994. Neutralizing antibodies to phocine distemper virus in Atlantic wairuses (Odobenus rosmarus rosmarus) from Arctic Canada. J. Wildl. Dis., 30: 90-94.

Duignan, P.J., House, C., Gerachi, J.R., Duffy, N., Rima, B., Walsh, M.T., Early, G., St. Aubin, D.J., Sadove, S., Koopman, H. and Rhinehart, H., 1995. Morbillivirus infection in cetaceans of the western Atlantic. Vet. Microbiology, Special Issue: Morbilliviruses, Vol. 44.

Grachev, M.A., Kumarev, V.P., Mamaev, L.V., Zorin, V.L., Baranova, L.V., Denikjna, N.N., Belikov, S.I., Petrov, E.A., Kolesnik, V.S., Kolesnik, R.S., Dorofeev, V.M., Beim, A.M., Kudelin, V.N., Nagieva, F.G. and Sidorov, V.N., 1989. Distemper virus in Baikal seals. Nature, 338: 209.

Haas, L., Subbarao, S.M., Harder, T., Liess, B. and Barrett, T., 1991. Detection of phocid distemper virus RNA in seal tissues using slot hybridization and the polymerase chain reaction amplification assay: genetic evidence that the virus is distinct from canine distemper virus. J. Gen. Virol., 72: 825-832.

Hall, A.J., Law, R.J., Harwood, J., Ross, H.M., Kennedy, S., Allchin, C.R., Campbell, L.A. and Pomeroy, P.P., 1992. Organochlorine levels in common seals (Phoca vitulina) which were victims and survivors of the 1988 phocine distemper epizootic. Sci. Total. Envir., 115: 145-162.

Helle, E., Olsson, M. and Jensen, S., 1976. PCB levels correlated with pathological changes in seal uteri. Ambio, 5: 261-263.

Kennedy, S., Smyth, J.A., McCullough, S.J., Allan, G.M. and McQuaid, S., 1988. Viral distemper now found in porpoises. Nature, 336: 21.

Kövamees, J., Blixenkrone-Møller, M., Sharma, B., Örvell, C. and Norrby, E., 1991. The nucleotide sequence and deduced amino acid composition of the hemagglutinin and fusion proteins of the morbillivirus phocid distemper virus. J. Gen. Virol., 72: 2959-2966.

Mamaev, L.V., Denikina, N.N., Belikov, S.I., Volchkov, V.E., Visser, I.K.G., Fleming, M., Kai, C., Harder, T.C., Liess, B., Osterhaus, A.D.M.E. and Barrett, T., 1995. Characterisation of morbilliviruses isolated from lake Baikal seals (Phoca sibirica). Vet. Microbiol., Special Issue: Morbilliviruses, Vol. 44. 
Morell, V., 1994. Canine-Distemper Virus - Serengeti's Big Cats Going to the Dogs. Science, 264: 1664.

Norrby, E. and Oxman, M.N., 1990. Measles virus. In: Fields, B.N. and Knipe, D.M. (Eds.), Virology. New York, Raven Press. pp. 1013-1044.

Olsson, M., Andersson, O., Bergman, A., Blomkvist, G., Frank, A. and Rappe, C., 1992. Contaminants and diseases in seals from Swedish waters. Ambio, 21: 561-562.

Osterhaus, A.D.M.E., Groen, J., UytdeHaag, F.G.C.M., Visser, I.K.G., Van de Bildt, M.W.G. and Klingeborn, B., 1988. Canine distemper virus in seals. Nature, 335: 403-404.

Osterhaus, A.D.M.E., UytdeHaag, F.G.C.M., Visser, I.K.G., Vedder, E.J., Reijnders, P.J.H., Kuiper, J. and Brugge, H.N., 1989a. Seal vaccination success. Nature, 337: 21.

Osterhaus, A.D.M.E., Groen, J., UytdeHaag, F.G.C.M., Visser, I.K.G., Van de Bildt, M.W.G., Bergman, A. and Klingeborn, B., 1989b. Distemper virus in Baikal seals. Nature, 338: 209-210.

Osterhaus, A.D.M.E. and Vedder, E.J., 1988. Identification of virus causing recent seal deaths. Nature, 335: 20.

Osterhaus, A.D.M.E. and Vedder, E.J., 1989. No simplification in the etiology of recent seal deaths. Ambio, 18: 297-298.

Reijnders, P.J.H., 1986. Reproductive failure in common seals feeding on fish from polluted coastal waters. Nature, 324: $456-457$.

Ross, P.S., Visser, I.K.G., Broeders, H.W.J., Van de Bildt, M.W.G., Bowen, W.D. and Osterhaus, A.D.M.E., 1992. Antibodies to phocine distemper virus in Canadian seals. Vet. Rec., 130: 514-516.

Ross, P.S., De Swart, R.L., Vedder, L.J., Reijnders, P.J.H., Van Loveren, H., Vos, J.G. and Osterhans, A.D.M.E., 1995. Contaminant-related suppression of delayed-type hypersensitivity and antibody responses in harbor seals fed herring from the Baltic Sea. Environ. Health Perspect., 103: 162-167.

Sharma, B., Norrby, E., Blixenkrone-Møller, M. and Kövamees, J., 1992. The nucleotide and deduced amino acid sequence of the $\mathrm{M}$ gene of phocid distemper virus (PDV). The most conserved protein of morbilliviruses shows a uniquely close relationship between PDV and canine distemper virus. Virus Res., 23: 13-25.

Stuen, S., Arnemo, J.M., Have, P., Osterhaus, A.D.M.E. and Moustgaard, A., 1994. Serological Investigation of Virus-Infections in Harp Seals (Phoca-Groenlandica) and Hooded Seals (Cystophora-Cristata). Vet. Rec., 134: 502-503.

Subramanian, A., Tanabe, S., Tatsukawa, R., Saito, S. and Miyazaki, N., 1987. Reduction in the testosterone levels by PCBs and DDE in Dall's porpoises of northwestern North Pacific. Mar. Pollut. Bull., 18: 643-646.

Van Bressem, M.F., Visser, I.K.G., Van de Bildt, M.W.G., Teppema, J.S., Raga, J.A. and Osterhaus, A.D.M.E., 1991. Morbillivrirus infection in Mediterranean striped dolphins (Stenella coeruleoalba). Vet. Rec., 129: 471472.

Van Bressem, M.F., Visser, I.K.G., De Swart, R.L., Örvell, C., Stanzani, L., Androukaki, E., Siakavara, K. and Osterhaus, A.D.M.E., 1993. Dolphin morbillivirus infection in different parts of the Mediterranean Sea. Arch. Virol., 129: 235-242.

Visser, I.K.G., Van de Bildt, M.W.G., Brugge, H.N., Reijnders, P.J.H., Vedder, E.J., De Vries, P., Groen, J., Walvoort, H.C., UytdeHaag, F.G.C.M. and Osterhaus, A.D.M.E., 1989. Vaccination of harbour seals (Phoca vitulina) against phocid distemper virus with two different inactivated canine distemper virus (CDV) vaccines. Vaccine, 7: 521-526.

Visser, I.K.G., Kumarev, V.P., Örvell, C., De Vries, P., Broeders, H.W.J., Van de Bildt, M.W.G., Groen, J., Teppema, J.S., Burger, M.C., UytdeHaag, F.G.C.M. and Osterhaus, A.D.M.E., 1990. Comparison of two morbilliviruses isolated from seals during outbreaks of distemper in North West Europe and Siberia. Arch. Virol., 111: 149-164.

Visser, I.K.G., Van Bressem, M.F., Barrett, T. and Osterhaus, A.D.M.E., 1993a. Morbillivirus infections in aquatic mammals. Vet. Res., 24: 169-178.

Visser, I.K.G., Van Bressem, M.F., De Swart, R.L., Van de Bildt, M.W.G., Vos, H.W., van der Heijden, R.W.J., Saliki, J.T., Örvell, C., Kitching, P., Kuiken, T., Barrett, T. and Osterhaus, A.D.M.E., 1993b. Characterization of morbilliviruses isolated from dolphins and porpoises in Europe. J. Gen. Virol., 74: 631-641.

Visser, I.K.G., Van der Heijden, R.W.J., Van de Bildt, M.W.G., Kenter, M.J.H., Orvell, C. and Osterhaus, A.D.M.E., 1993c. Fusion protein gene nucleotide sequence similarities, shared antigenic sites and phylogenetic analysis suggest that phocid distemper virus type 2 and canine distemper virus belong to the same virus entity. J. Gen. Virol., 74: 1989-1994.

Visser, I.K.G., Vedder, E.J., Vos, H.W., Van de Bildt, M.W.G. and Osterhaus, A.D.M.E., 1993d. Continued presence of phocine distemper virus in the Dutch Wadden Sea seal population. Vet. Rec., 133: 320-322. 